\title{
THE DEVELOPMENT OF NEW CASTING ALLOYS INTENDED FOR OPERATION UNDER EXTREME CONDITIONS AND SOME TECHNIQUES OF MAKING CASTINGS FROM THEM
}

\author{
Mikhail Yamshinskij \\ Department of foundry of ferrous and nonferrous metals \\ National Technical University of Ukraine "KPI" \\ 37 Peremohy ave., Kyiv, Ukraine, 03056 \\ yamshinskiy@ukr.net \\ Grigoriy Fedorov \\ Department of foundry of ferrous and nonferrous metals \\ National Technical University of Ukraine "KPI" \\ 37 Peremohy ave., Kyiv, Ukraine, 03056 \\ foundry@iff.kpi.ua \\ Anatoliy Verkhovliuk \\ Department of foundry of ferrous and nonferrous metals \\ National Technical University of Ukraine "KPI" \\ 37 Peremohy ave., Kyiv, Ukraine, 03056 \\ vam@ptima.kiev.ua
}

\begin{abstract}
The article studies new heat-resistant and wear resistant materials for operation under extreme conditions, especially in the power industry. The methods that improve the quality of a metal in metal castings through the influence of alloying elements on its structure and properties have been considered. These methods are very effective for reducing the tendency of a metal to form a coarse-grained structure. The paper describes optimal techniques for melting special alloys in induction and electric furnaces. A set of rules for the selection of a melting temperature before pouring a metal into the casting forms depending on the dimensions, wall thickness, geometry of castings have been determined. The behavior of new alloys under the conditions of high temperatures, aggressive environments has been studied.

It has been established that heat-resistant $\mathrm{Cr}$-Al steels exhibit high heat resistance and wear resistance properties; they 6-8 times surpass $\mathrm{Cr}-\mathrm{Ni}$ steels in oxidation resistance. The proposed $\mathrm{Cr}-\mathrm{Mn}$ cast iron processed in an integrated manner with REM (rare earth metals) and $\mathrm{Ti}$ is superior to a basic cast iron in conditions of a heavy wear. Numerous industrial trials confirm the usefulness of recommended new casting materials for use under extreme conditions.

Keywords: heat-resistant steel, $\mathrm{Cr}-\mathrm{Al}$ steel, heat resistance, aggressive environment, wear-resistant cast iron, ash-handling pump, ash pump.

(C) Mikhail Yamshinskij, Grigoriy Fedorov, Anatoliy Verkhovliuk

\section{Introduction}

High (up to $1350{ }^{\circ} \mathrm{C}$ ) and low (to $-190^{\circ} \mathrm{C}$ ) temperatures, aggressive environments, intensive abrasive, impact-abrasive and hydro-abrasive wears and other factors are considered as extreme conditions for the operation of metal goods.

Fe-based heat-resistant alloys like $\mathrm{Cr}, \mathrm{Cr}-\mathrm{Ni}$ and $\mathrm{Cr}$-Al steels are classified as the materials operating in the conditions of high temperatures and aggressive environments [1,2]. They are used for production of moulded parts for combustion appliances of boiler units at thermal power plants, equipment for metallurgical, chemical and high temperature technologies machine-building companies.

The analysis of operating conditions of such details has defined that heat-resistant alloys, recently being used for their manufacture, have significant drawbacks: their structure includes expensive and scarce elements (nickel, cobalt, molybdenum and others). They are low-tech as a casting material (containing small percentage of carbon - up to $0.1 \%$ ) and have limited perfor-
\end{abstract}


mance characteristics (e. g., the maximum operating temperature does not exceed $1100{ }^{\circ} \mathrm{C}$ ). Thus, new alloys must have high melting temperatures and thermal stability (oxidation resistance, heat resistance and growth resistance), satisfactory casting properties, be inexpensive and available.

Development of new alloys requires deep knowledge of their likely behavior at high temperatures and in aggressive environments. This makes it possible to select a group of elements capable to maximize service features of alloys with saving satisfactory casting and high mechanical properties.

The alloying of Fe-based steels essentially changes their structure and properties due to the reduction of thermal conductivity of metal, changes in the crystallization processes and, in many cases, the deterioration of casting properties. The role of alloying elements in heat-resistant alloys consists primarily of changing a scale's composition and structure, the kinetics of metal oxidation in various aggressive environments.

Such elements as carbon, chromium, silicon, aluminum, titanium and others are the main part of heat-resistant steels. Let's consider the impact some of them have on main technological properties of these alloys.

\section{Experimental procedures}

The alloys were melted in an induction crucible furnace IST-0.06 with a basic lining using the refining method of the estimated amount of a charge [5].

The fluidity of the alloys was determined using a Kerry's spiral special cup, allowing to stabilize metal pressure and temperature in each experiment [6].

Linear shrinkage was studied on a special appliance, which allows linear changes of a sample with the dimensions $200 \times 25 \times 20 \mathrm{~mm}$ to be turned into a proportional change in voltage during a shrink process using a potentiometric linear encoder. A signal from a sensor was recorded on a chart record of a XY recorder N-703 with a functional dependence $\varepsilon=f\left(\mathrm{t}^{\circ} \mathrm{C}\right)$.

The resistance of alloys to crack development was determined using a circular process sample with a diameter $160 \mathrm{~mm}$, wall thickness $7 \mathrm{~mm}$ and $100 \mathrm{~mm}$ in height. The cross section of the thermal unit was $30 \times 19 \mathrm{~mm}$ throughout the height of the sample. To slow the shrinkage down, cores made from liquid glass mixture were utilized. The criterion of crack resistance is the crack area, which is formed on the inner surface of the thicker area of the sample. The area of the crack was determined based on the print on a scale - coordinate paper [7].

Mechanical properties of the alloys were studied using standard techniques. Heat resistance of steel was investigated with a tube - type furnace, which allows to heat samples $20 \mathrm{~mm}$ long and $10 \mathrm{~mm}$ in diameter up to $1400^{\circ} \mathrm{C}$ in various gas atmospheres and soak for a long time [8].

The study of wear resistance of the cast iron was carried out on a special appliance, which models real operation conditions of details in a hydro-abrasive environment (a mixture of quartz pit sand and water) by means of rotating samples $65 \times 25 \times 10 \mathrm{~mm}$ in size.

To study the structure, hardness and microhardness of structural components samples cut from moulded prismatic pieces $100 \times 30 \times 20 \mathrm{~mm}$ in size were used. The cross section of these samples corresponds to the average cross section of the walls of details of ash pumps.

\section{Results}

\section{1. The effect of $\mathrm{Cr}$ and $\mathrm{Al}$ on casting properties of heat-resistant alloys}

Technological properties of heat-resistant steels are determined by content of main elements $-\mathrm{Cr}$ and $\mathrm{Al}$ [9]. The effects of $\mathrm{Cr}$ in the concentration range from 13 to $37 \%$ and $\mathrm{Al}$ to $7.1 \%$ were studied. The results of changes of main casting characteristics of $\mathrm{Cr}$ steels in accordance with the content of these elements are shown in Fig. 1.

It was established that the increase in the concentration of $\mathrm{Cr}$ in steel improves practical fluidity due to the decrease in temperature of liquidus and reduced crystallization interval in accordance with the phase diagram of $\mathrm{Fe}-\mathrm{Cr}$.

The increase of Al content in high-chromium steels up to 1.5-2.0\% keeps their practical fluidity on a high level. Further increase in Al content reduces fluidity of steels as a result of intensive foam formation in a metal. 
Thus, to maintain the high fluidity of Cr steels the content of Al should not exceed $2 \%$ (Fig. 1, a).

$\mathrm{Cr}$ and $\mathrm{Al}$ are referred to elements that help in formation of an alloyed ferrite, which has a lower shrinkage ratio when compared to an alloyed austenite [10]. Therefore, the increase in concentration level of $\mathrm{Cr}$ and $\mathrm{Al}$ in steels reduces the linear shrinkage (Fig. 1, b) and improves crack resistance of alloys.
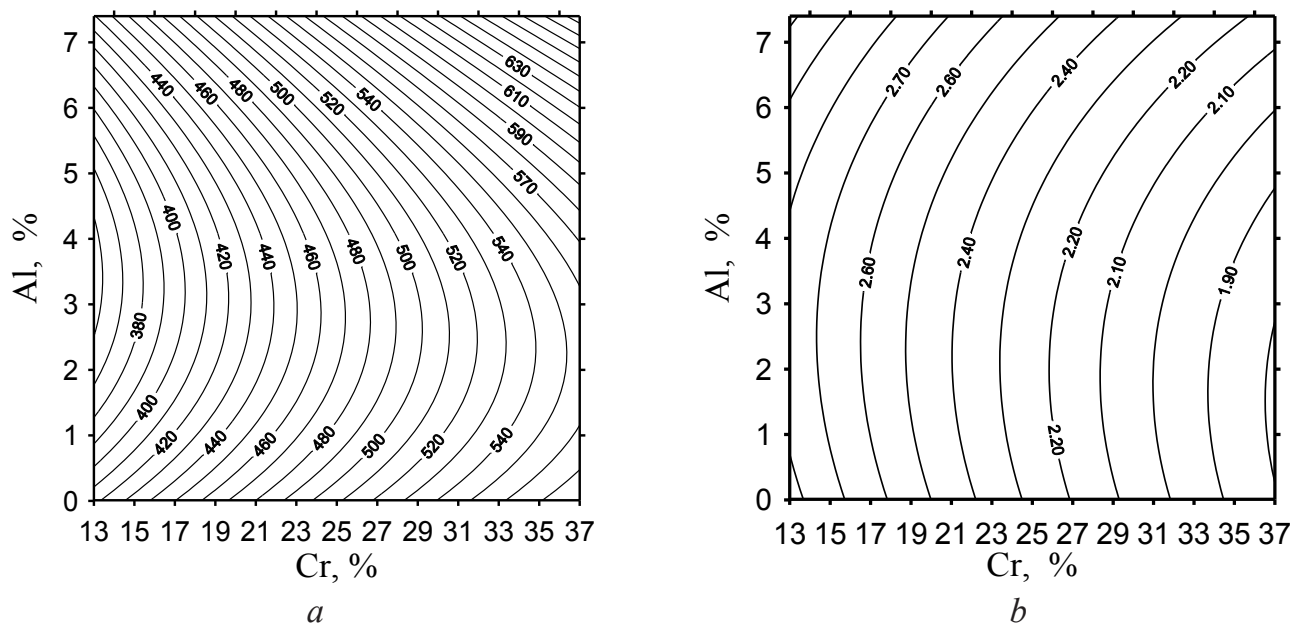

Fig. 1. Casting properties of heat resistant steels depending on the $\mathrm{Cr}$ and $\mathrm{Al}$ content: $a$ - practical fluidity; $b$ - a linear shrinkage

The reduction of steels' thermal conductivity, after the rise of $\mathrm{Cr}$ and $\mathrm{Al}$ content, increases the defects of a shrinkage type and a concentrated shrinkage cavity $[9,10]$.

3. 2. Mechanical properties of heat-resistant steels depending on the content of $\mathrm{Cr}$ and $\mathrm{Al}$

The increase of $\mathrm{Cr}$ and $\mathrm{Al}$ concentration in the investigated steels is accompanied by a reduction of their density, because both $\mathrm{Cr}$ and $\mathrm{Al}$ have less density as compared to $\mathrm{Fe}$ (7160 and $2710 \mathrm{~kg} / \mathrm{m}^{3}$ against $7862 \mathrm{~kg} / \mathrm{m}^{3}$ accordingly).

Investigated steels have a coarse - grained structure, which can't be changed by any mode of heat treatment. As a result, their strength properties at normal temperatures are much lower than in same steels with a fine - grained structure.

The increase of $\mathrm{Cr}$ concentration in the investigated range promotes grain growth from 87 to 120 microns, and from 69 to 87 microns with the increase of $\mathrm{Al}$ content up to $3 \%$. This change of the grain's size reduces both strength (Fig. 2, a) and ductility (Fig. 2, b) of heat-resistant steels.
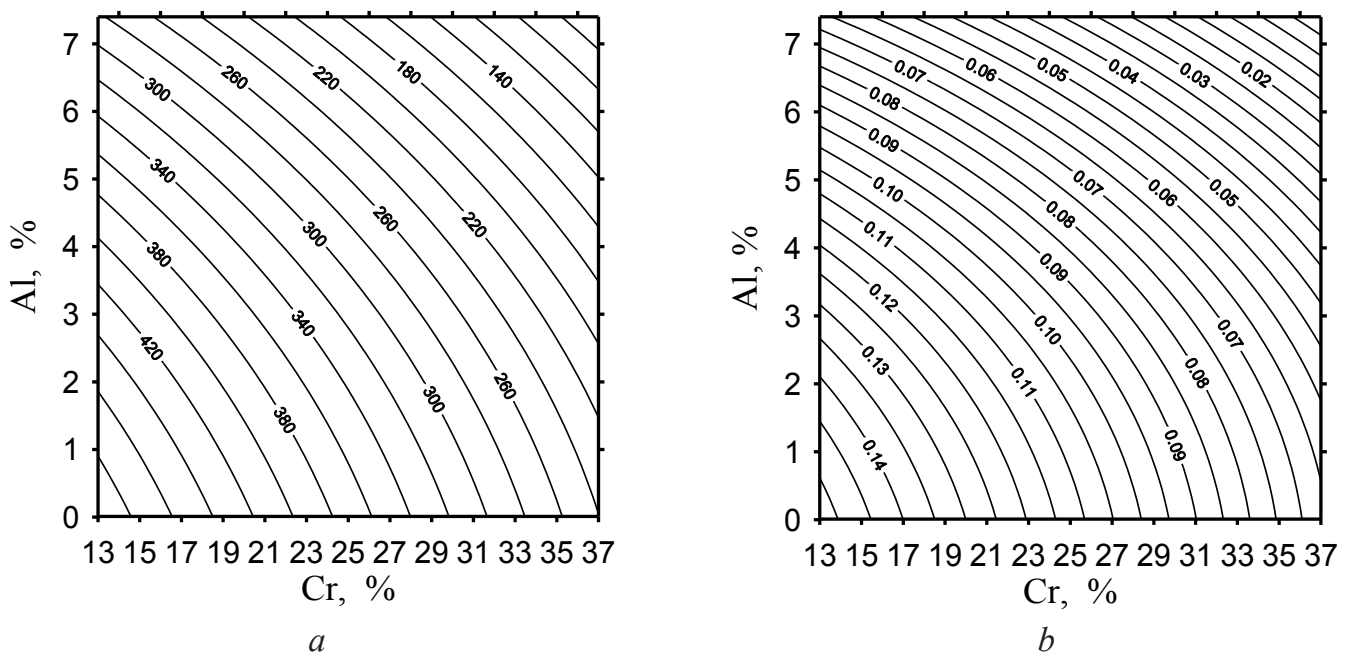

Fig. 2. The change of mechanical properties of heat resistant steels depending on the $\mathrm{Cr}$ and $\mathrm{Al}$ content: $a$ - ultimate tensile strength; $b$-impact strength 
The studies have found that $\mathrm{Al}$ content in the heat resistant steels should be determined by the minimum, which maintains their high heat resistance, and the maximum, when casting and mechanical properties are getting worse.

Thus, considering casting properties optimum content in heat-resistant steels of $\mathrm{Cr}$ should be $28-32 \%$ and Al $1.5-2.0 \%$.

\section{3. The influence of carbon and titanium on casting properties of $\mathrm{Cr}$-Al steels}

The improvement of properties of heat-resistant steels can be achieved by further processing them with titanium, vanadium, niobium and other elements. The cheapest and the most effective is titanium $[11,12]$.

The effect of $\mathrm{C}$ with concentrations ranging from 0.08 to $0.81 \%$ and $\mathrm{Ti}$ up to $1.45 \%$ on casting and mechanical properties has been studied.

The determination of the optimum ratio of $\mathrm{Ti}$ and $\mathrm{C}$ in $\mathrm{Cr}$-Al steels with regard to their impact on casting, mechanical and special properties are of theoretical and practical interest.

It has been found that the increase of $\mathrm{C}$ improves practical fluidity of all investigated steels. Addition of Ti up to $0.35 \%$ also increases the fluidity of steels (Fig. 3, a).

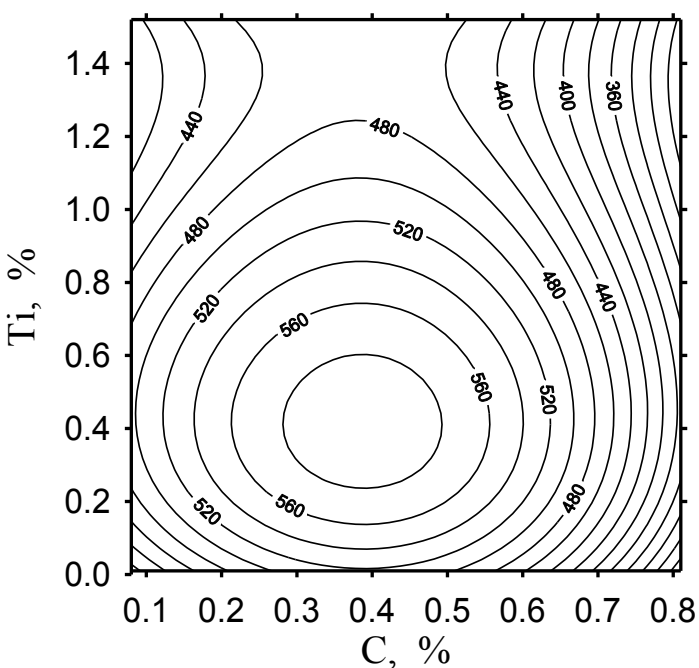

$a$

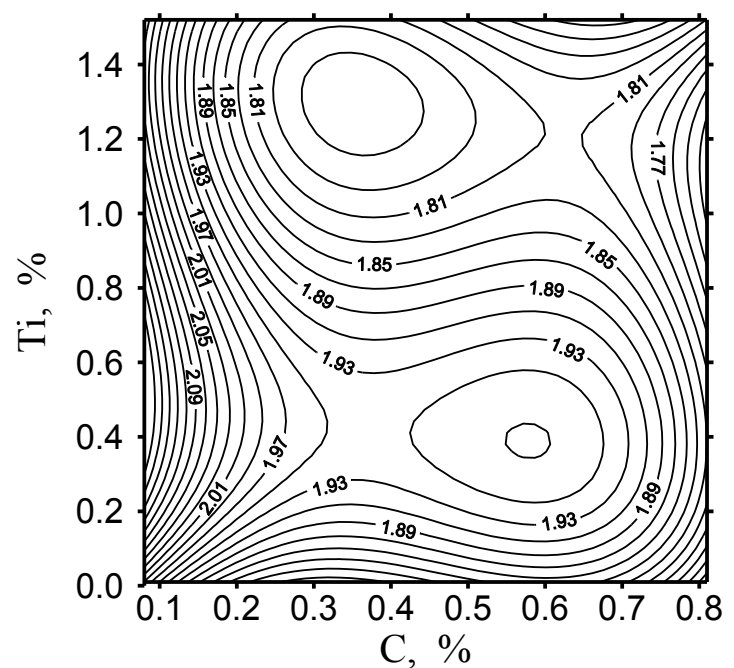

b

Fig. 3. The change of casting properties of $\mathrm{Cr}-\mathrm{Al}$ steels depending on the $\mathrm{C}$ and Ti content:

$$
a \text { - fluidity; } b \text { - linear shrinkage }
$$

The results of the study the influence of $\mathrm{C}$ and $\mathrm{Ti}$ on the linear shrinkage are shown in Fig. 3, b. Crack resistance change in relation to $\mathrm{C}$ and $\mathrm{Ti}$ content in steels has the same character as the linear shrinkage.

\section{4. Mechanical properties of $\mathrm{Cr}$-Al steel alloyed with titanium}

The change in $\mathrm{C}$ concentration from 0.08 to $0.81 \%$ contributes to grain refinery of a steel from 180 to 40 microns. This increases the amount of carbides, located both at the grain boundaries and in the middle of them.

Titanium additives to $0.35 \%$ reduce the grain size from 82 to 48 microns. Such structural change improves both strength (Fig. 4, a) and plastic (Fig. 4, b) properties of heat-resistant Cr-Al steel.

Therefore, it has been established by the researches, that medium-carbon $\mathrm{Cr}-\mathrm{Al}$ steel containing $0.30-0.35 \%$ of $\mathrm{C}$ and $0.25-0.45 \%$ of Ti has the best combination of casting and mechanical properties.

Technological properties of steels are shown in the Table $\mathbf{1 .}$ 

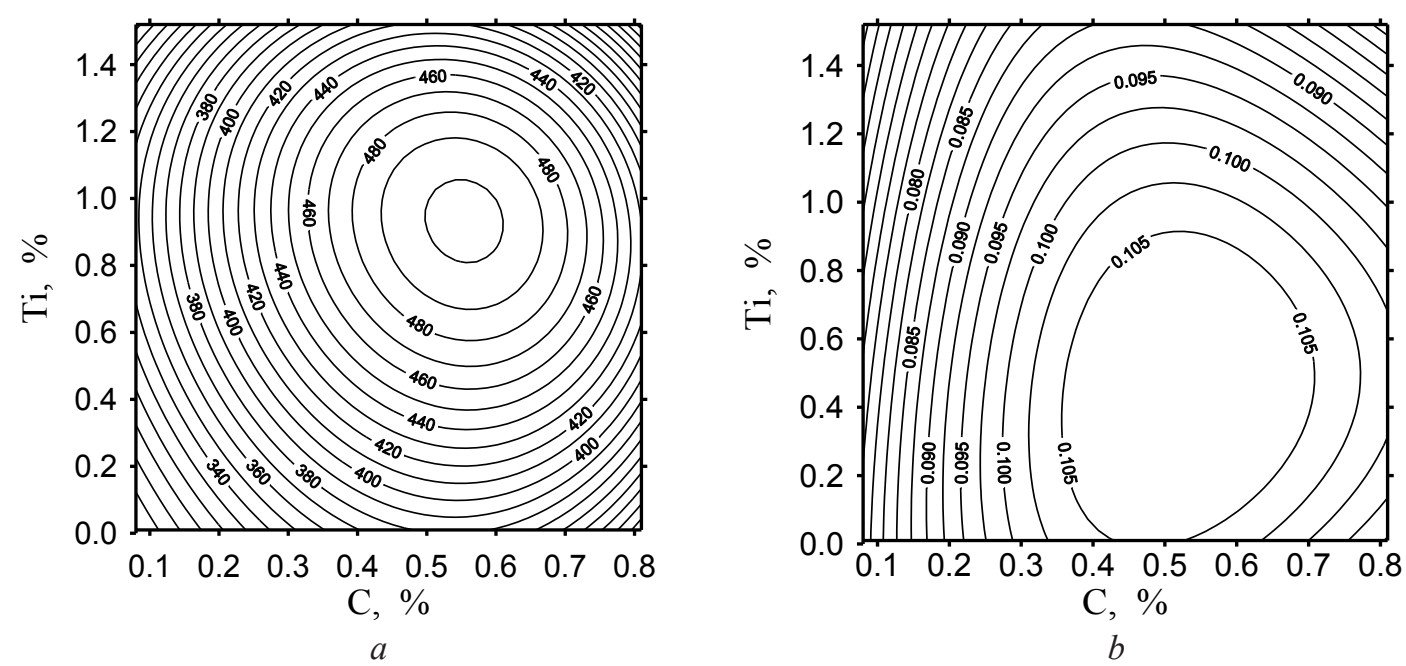

Fig. 4. The change of mechanical properties of $\mathrm{Cr}-\mathrm{Al}$ steels depending on the $\mathrm{C}$ and Ti content: $a$ - ultimate tensile strength; $b$ - impact strength

Table 1

Technological properties of $\mathrm{Cr}-\mathrm{Al}$ steels

\begin{tabular}{ccc}
\hline № & Properties & Parameters \\
\hline 1 & Fluidity at $1580{ }^{\circ} \mathrm{C}, \mathrm{mm}$ & $460-630$ \\
2 & Linear shrinkage at the temperature of metal before pouring into the mold $1580{ }^{\circ} \mathrm{C}, \%$ & $1.75-2.30$ \\
3 & Linear shrinkage at the temperature of metal before pouring into the mold $1700{ }^{\circ} \mathrm{C}, \%$ & $1.30-1.65$ \\
4 & Cracks' squire on a technological sample with the diameter $160 \mathrm{~mm}$ and height & $0.75-1.50$ \\
5 & $100 \mathrm{~mm}$ before pouring a metal into the mold at the temperature of $1580{ }^{\circ} \mathrm{C}, \mathrm{cm}^{2}$ & $11.6-13.5$ \\
6 & Full volume shrinkage at $1580{ }^{\circ} \mathrm{C}, \%$ & $360-450$ \\
7 & Ultimate tensile strength, $\mathrm{MPa}$ & $0.09-0.11$
\end{tabular}

\section{5. The investigation of special properties of $\mathrm{Cr}-\mathrm{Al}$ steels}

Oxidation resistance of steels was determined in an atmosphere of overheated air to $1300{ }^{\circ} \mathrm{C}$, air $+25 \%$ of water vapor, air $+45 \%$ of $\mathrm{CO}_{2}$, air $+45 \%$ of water vapor. The results of the study are presented in the Table 2.

Table 2

Oxidation resistance of $\mathrm{Cr}-\mathrm{Al}$ steel in relation to its $\mathrm{Al}$ content and experimentation environment (Test conditions: temperature $-1300^{\circ} \mathrm{C}$, time $100 \mathrm{~h}$ )

\begin{tabular}{cccccccc}
\hline No & Environment & \multicolumn{5}{c}{$\begin{array}{c}\text { Oxidation resistance, } \mathbf{M g} / \mathbf{c m}^{2} \\
\text { The aluminium content, \% }\end{array}$} \\
\hline & & 0.02 & 0.92 & 1.96 & 2.84 & 5.05 & 6.76 \\
1 & & 9.85 & 6.10 & 4.00 & 3.50 & 3.20 & 3.18 \\
2 & air $+25 \% \mathrm{H}_{2} \mathrm{O}$ & 12.80 & 8.20 & 5.35 & 4.10 & 3.65 & 3.58 \\
3 & air $+45 \% \mathrm{CO}_{2}$ & 16.10 & 9.75 & 6.15 & 4.85 & 3.95 & 3.90 \\
4 & ai $+45 \% \mathrm{H}_{2} \mathrm{O}$ & 17.95 & 11.05 & 7.85 & 5.90 & 4.45 & 4.20
\end{tabular}




\section{in Table 3.}

Comparison of oxidation resistance of heat resistant steels of different classes is shown

Table 3

Oxidation resistance of heat-resistant steels of different classes in the atmosphere of overheated air

\begin{tabular}{cccc}
\hline № & Grade of steel & \multicolumn{2}{c}{ Oxidation resistance (mass loss), $\mathbf{g r} / \mathbf{m}^{\mathbf{2}} \mathbf{h}$} \\
\hline 1 & DIN. GX16CrNi25-21 & $\mathbf{1 2 5 0}^{\circ} \mathbf{C}$ & $\mathbf{1 3 0 0}^{\circ} \mathbf{C}$ \\
\hline 2 & DIN. X15CrNiSi25-20 & $3.9-4.2$ & $4.5-4.8$ \\
3 & X30Cr30A12Ti & $2.7-3.1$ & $3.0-3.5$ \\
4 & X15Cr26A12NiTiCu & $0.4-0.5$ & $0.6-0.7$ \\
\end{tabular}

Consequently, heat-resistant $\mathrm{Cr}-\mathrm{Al}$ steels possess high oxidation resistance, temperature resistance and durability. They are 6-8 times less sensitive to oxidation than $\mathrm{Cr}-\mathrm{Ni}$ steels at operation temperatures $1250{ }^{\circ} \mathrm{C}$ and 1,5-2,0 times more heat resistant, 2,0-3,0 times more durable.

Ferrite $\mathrm{Cr}-\mathrm{Al}$ steels are characterized by the highest electrical resistance, so they can be used to produce heaters for heat-treatment furnaces, moulded resistors, and other products [13].

New nickel-free heat resistant steels can be used in manufacturing moulded parts in the power industry, ferrous metallurgy, chemical and other industries [14-16].

The examples of moulded parts of different sizes, geometry, mass, which were produced with different casting techniques are shown below (Fig. 5). Tips and nozzles are produced in an expendable sand-clay form. The use of parts made from these steels (burners tops, nozzles, gas nozzles and others) at thermal power plants allows 4-6 times to extend their service life, cut cost, reduce maintenance costs, fuel consumption for electricity production and completely eliminate alloys, containing nickel, cobalt, molybdenum, from heat-resistant structures $[17,18]$.

The power industry is one of the main consumers of wear-resistant alloys. Generic items from these alloys are shown in the Fig. 6. Details of solid fuel preparation systems and systems of ash and slag removal from boilers are being in service here under the conditions of intensive abrasive or hydro-abrasive wear [19].

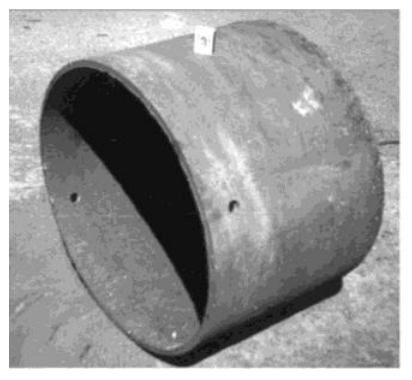

$a$

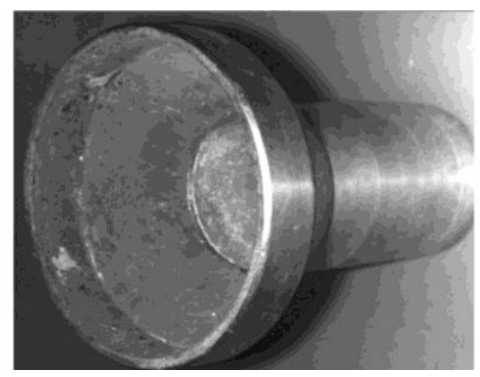

$b$

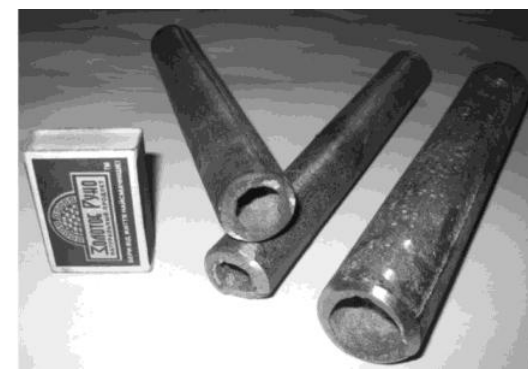

$c$

Fig. 5. Generic items for combustion appliances of thermal power stations (diameter 300, 600 and $930 \mathrm{~mm}$; height - $600 \mathrm{~mm}$; wall thickness - 15-20 mm): $a$ - a nozzle №1; $b$ - a nozzle №2; $c$ - tips of gas nozzles (length $220 \mathrm{~mm}$, diameter 26 and $35 \mathrm{~mm}$, wall thickness $5 \mathrm{~mm}$, mass 0.6 and $0.9 \mathrm{~kg}$ )

The period of operation of the pump is usually limited by wear of an impeller or a body, which is made mainly of wear-resistant white cast iron $280 \mathrm{H} 28 \mathrm{~N} 2$ brand. The pump breaks down 
and can not create necessary pressure when through holes are formed in an impeller wheel or in a body. At the same time, wear of the impeller wheel or body doesn't exceed 5-10\%.

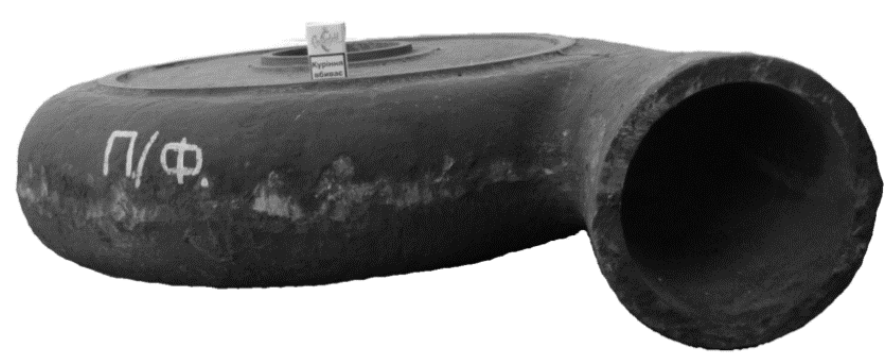

$a$

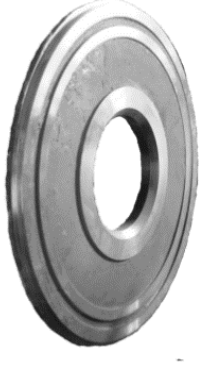

b

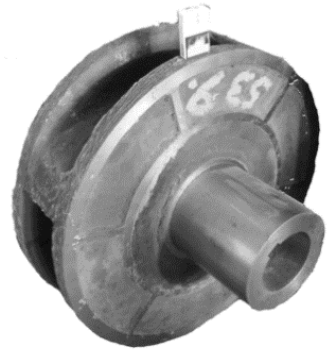

C

Fig. 6. Fast wearing parts of ash pumping systems of ash pumps at thermal power stations: $a-\mathrm{a}$ body, $b-\mathrm{a}$ disk, $c-$ a wheel

The improvement of the structure of the alloy, its technological and operational properties becomes possible due to additional micro-alloying and modification. Modification by several elements simultaneously (i. e., complex modification) is especially effective [20, 21].

The influence of complex modification on the structure and properties of wear-resistant Cr-Mn cast iron with a certain chemical composition, \%: C - 2,8-3,1; $\mathrm{Cr}-19-21$; $\mathrm{Mn}-4,2-4,4$; $\mathrm{Si}-0,6-0,9 ; \mathrm{S} \leq 0,05 ; \mathrm{P} \leq 0,05$, previously developed by the authors, have been studied in this work [22]. After experimental samples from the standard, basic cast iron had been poured, Ti in the form of ferrotitanium FTi35 was loaded into a crucible of the furnace. REM in the form of a rich alloy containing $48.5 \%$ of Ce were also loaded in the crucible of the furnace just before tapping the metal from the furnace.

The introduction of Ti together with an element, which has a high affinity to sulfur and other harmful impurities, has scientific and practical interest. Such promising elements are REM [24].

Chemical composition of the investigated cast irons is shown in Table 4.

Table 4

Chemical content of investigated cast irons

\begin{tabular}{ccccccccc}
\hline $\begin{array}{c}\text { Cast iron } \\
\text { index }\end{array}$ & C & Cr & Mn & Si & Ti & REM* & Plements content, \% & S \\
\hline 9.1 & 2.91 & 18.9 & 4.38 & 0.64 & - & - & 0.05 & 0.05 \\
9.2 & 2.88 & 18.5 & 4.30 & 0.65 & 0.20 & 0.10 & 0.05 & 0.05 \\
9.3 & 3.00 & 19.8 & 4.24 & 0.74 & 0.15 & 0.20 & 0.05 & 0.05 \\
9.4 & 2.90 & 19.2 & 4.32 & 0.72 & 0.13 & 0.50 & 0.05 & 0.05
\end{tabular}

Note: * estimated amount

This work was carried out for details working in hydro-abrasive environments. It was found that simultaneous addition of Ti and REM in the cast iron has significant influence on the structure and mechanical properties of the basic $\mathrm{Cr}-\mathrm{Mn}$ cast iron. An alloy treated with $0.15 \%$ of $\mathrm{Ti}$ and $0.2 \%$ of REM has maximum durability and microhardness of austenite grains. The microhardness of the chromium carbides varied at the level 11-14 GPa and didn't depend on Ti or REM content. The hardness of the surface of original and modified samples shifted slightly and reached to $48-50 \mathrm{HRC}$. This is explained by the fact that main structural changes and according- 
ly changes of the service properties of the alloy occur during the solidification process inside of the sample rather than on its surface.

The structure of the original cast iron consists of branched primary dendrites of austenite and the eutectic $\gamma+(\mathrm{Cr}, \mathrm{Fe}, \mathrm{Mn})_{7} \mathrm{C}_{3}$ (Fig. 7). Simultaneous modification of the cast iron with Ti and REM significantly refines the structure of the original Cr-Mn cast iron. The width and especially the length of primary austenite dendrites is greatly reduced in the central part of samples.

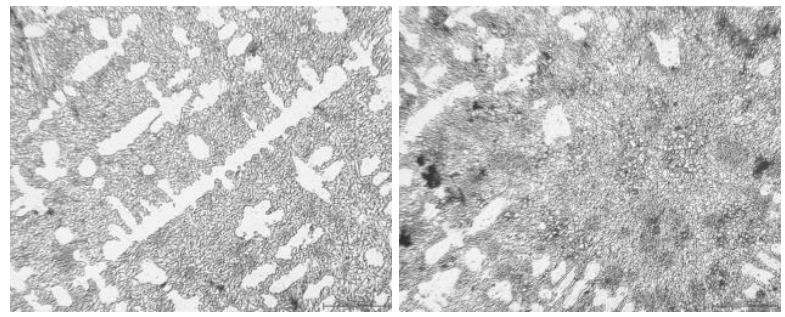

$a$

$b$

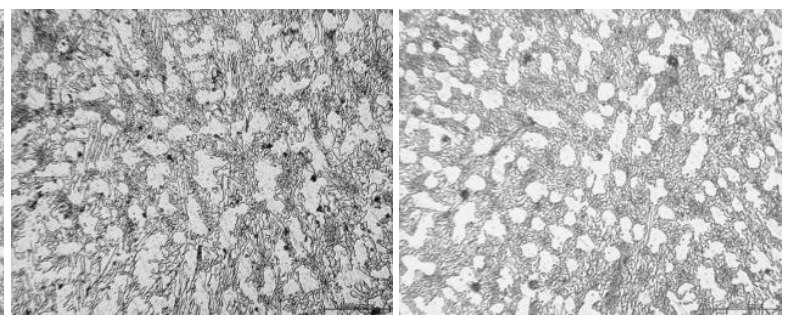

$c$

$d$

Fig. 7. The structure of Cr-Mn cast iron modified with Ti and REM $(\times 100)$ : $a$ - without Ti and REM; $b-0.2 \% \mathrm{Ti}$ and $0.1 \% \mathrm{REM} ; c-0.15 \% \mathrm{Ti}$ and $0.2 \% \mathrm{REM}$; $d-0.13 \%$ Ti and $0.5 \%$ REM

The addition of $\mathrm{Ti}$ in the cast iron facilitates the formation of carbides and carbonitrides, located mainly in the austenite and at the boundaries of the matrix-carbide phase. In chromium carbides they are practically absent. Taking into account the correspondence of crystalline grids' types, they are the centers of austenite crystallization and modify a liquid alloy on the type II. REM additives stimulate the modification of a liquid alloy on the type I. Ce and its compounds, formed before the crystallization of the alloy, are adsorbed like surface - active agents at the border of growing austenite dendrites, restricting their growth. REM effectively binds the sulfur and oxygen in Cr-Mn cast iron and is a part of sulphides and oxysulphides mainly of spherical shape. REM oxysulphides are uniformly spread in the structure, their number gets bigger as the total content of REM in the alloy increases. In addition, there are inclusions in which sulfides of REM are close to titanium carbonitrides. Taking into consideration the high affinity of Ti to sulfur, it can be assumed that these are oxycarbosulphides of complex chemical composition.

Structural studies of pickled samples at high magnification on the optical and scanning electron microscopes have established that within austenite dendrites modified by REM and Ti there are fine particles of size 1-4 mm (Fig. 7, b). The highest number of such inclusions are found in alloys containing REM 0,2 and $0,5 \%$.

The cast iron modified with $0.2 \%$ of REM and $0.15 \%$ of Ti has wear resistance $15 \%$ higher than the original one. Pilot tests have confirmed the efficiency of such cast iron for use in manufacturing pieces of the hydraulic ash transport system machinery at thermal power plants $[25,26]$.

\section{Conclusion}

1. $\mathrm{Cr}-\mathrm{Al}$ steel with the following chemical composition of $\%$ : $\mathrm{C}=0.25-0.35 ; \mathrm{Cr}=28.0-32.0$; $\mathrm{Al}=1.5-2.5 ; \mathrm{Mn}=0.6-0.8 ; \mathrm{Si}=0.5-1.0$ has the best combination of casting, mechanical and special properties. $\mathrm{P}$ and $\mathrm{S}$ content should be not more than $0.025 \%$ for each element.

2. New heat-resistant nickel-free $\mathrm{Cr}-\mathrm{Al}$ steels may be used for the production of moulded parts of equipment for high temperatures technologies.

3. To produce moulded parts working under conditions of intensive wear, Cr-Mn cast iron additionally processed with titanium additives in amount of $0.15-0.2 \%$ and REM in amount of $0.15-0.25 \%$ (estimated) should be used. 


\section{References}

[1] Makarevich, O. P., Fedorov, G. E., Platonov, E. O. (2005). Virobnictvo vilivkiv iz special'nih stalej. Kiev: Vidavnictvo NTUU «KPI», 712.

[2] Fedorov, G. E., Jamshinskij, M. M., Platonov, E. A., Ljutyj, R. V. (2013). Stal'noe lit'e. Monografija. Kiev: PAO «Vipol», 896.

[3] Jamshins'kij, M. M., Fedorov, G. E., Platonov, E. A. (2004). Optimizacija himichnogo skladu zharostijkih hromoaljuminievih stalej zalezhno vid umov ekspluataciï litih detalej. Naukovi visti Naciona-l'nogo tehnichnogo universitetu «KPI», 5, 68-74.

[4] Jamshinskij, M. M., Fedorov, G. E., Platonov, E. A., Kuz'menko, A. E. (2005). Vlijanie tehnologicheskih faktorov na strukturu i svojstva zharostojkih hromoaljuminievyh stalej. Litejnoe proizvodstvo, 1, 38-45.

[5] Jamshins'kij, M. M. (2003). Vdoskonalennja tehnologiï viplavljannja zharostijkih splaviv. Metaloznavstvo ta obrobka metaliv, 1, 42-43.

[6] Jamshinskij, M. M., Fedorov, G. E., Platonov, E. A., Kuz'menko, A. E. (2005). Vlijanie struktury na mehanicheskie i jekspluatacionnye harakteristiki hromoaljuminievyh stalej. Processy lit'ja, 4, 15-21.

[7] Jamshins'kij, M. M., Fedorov, G. E. (2004). Metodi pidvishhennja vlastivostej litih zharostijkih detalej. Naukovi visti Nacional'nogo tehnichnogo universitetu «KPI», 4, 98-104.

[8] Jamshins'kij, M. M., Fedorov, G. E., Platonov, E. A. (2004). Special'ni vlastivosti livarnih hromoaljuminievih stalej. Metaloznavstvo ta obrobka metaliv, 3, 14-19.

[9] Jamshinskij M. M., Fedorov G. E. (2015). Litejnye i mehanicheskie svojstva zharostojkih stalej. Metallurgija. Mashinostorenie, 2, 17-24.

[10] Jamshinskij, M. M., Fedorov, G. E., Platonov, E. A., Kuz'menko, A. E. (2009). Novye zharostojkie beznikelevye stali i tehnologii izgotovlenija iz nih lityh detalej, rabotajushhih pri temperaturah do $1300{ }^{\circ} \mathrm{C}$. Visnik DDMA, 1, 300-306.

[11] Jamshinskij, M. M., Veres, I. A., Fedorov, G. E., Soboljuk, O. V., Nazarenko V. S. (2011). Kompleksnoe issledovanie vlijanija ugleroda i titana na tehnologicheskie svojstva zharostojkih hromoaljuminievyh stalej. Metall i lit'e Ukrainy, 1, 29-32.

[12] Jamshinskij, M. M., Fedorov, G. E., Platonov, E. A. (2004). Jekspluatacionnye svojstva litejnyh hromoaljuminievyh stalej. Litejnoe proizvodstvo, 9, 11-14.

[13] Jamshinskij, M. M., Fedorov, G. E., Platonov, E. A. (2013). Fizicheskie i special'nye svojstva litejnyh hromoaljuminievyh stalej. Lit'e i metallurgija, 4, 65-70.

[14] Jamshinskij, M. M., Fedorov, G. E., Platonov, E. A. (2014). Kinetika okisnennja hromoaljumini€vih stalej. Visnik Donbas'koï derzhavnoï mashinobudivnoï akademiï, 1, 167-173.

[15] Jamshins'kij, M. M., Fedorov, G. E., Radchenko, K. S. (2015). Termostijkist' zharostijkih stalej dlja roboti v ekstremal'nih umovah. Visnik Donbas'koï derzhavnoï mashinobudivnoï akademiï, $3,33-37$.

[16] Jamshins'kij, M. M., Fedorov, G. E., Platonov, E. A., Radchenko, K. S. (2014). Okalinostijkist' hromoaljuminiєvih stalej i rozrahunok parametrichnih diagram. Visnik NTUU «KPI». Serija mashinobuduvannja, 1, 25-30.

[17] Jamshinskij, M. M., Fedorov, G. E., Platonov, E. A., Kuz’menko, A. E., Nazarenko, V. S. (2009). Povyshenie special'nyh svojstv zharostojkih hromoaljuminievyh stalej mikrolegirovaniem i modificirovaniem. Visnik DDMA, 1, 220-225.

[18] Yamshinskij, M. (2015). Heat-resistance of heat-resistant Cr-Al steels for work under extreme conditions. Proceedings of the IInd International Scientific and Practical Conference "Science and Education - Our Future", (November 22-23, Ajman, UAE), 55-57.

[19] Garber, M. E. (2010). Iznosostojkie belye chuguny: svojstva, struktura, tehnologija, jekspluatacija. Moscow: Mashinostroenie, 280.

[20] Jamshinskij, M. M., Radchenko, K. S., Fedorov, G. E. (2011). Optimizacija himicheskogo sostava iznosostojkih vysokolegirovannyh belyh chugunov. Metall i lit'e Ukrainy, 1, 21-24.

[21] Jamshinskij, M. M., Radchenko, K. S., Fedorov, G. E. (2011). Vlijanie mikrolegirovanija i modificirovanija na strukturu i svojstva iznosostojkogo hromomargancevogo chuguna. Visnik DDMA, 4, 133-140. 
[22] Platonov, E. A, Fedorov, G. E., Kuz’menko, A. E., Jamshinskij, M. M. (2009). Patent № 38928 Znosostijkij chavun, opubl. 26.01.2009.

[23] Jamshinskij, M. M., Fedorov, G. E., Platonov, E. A., Kuz'menko, A. E., Radchenko, K. S. (2009). Pidvishhennja gidroabrazivnoï znosostijkosti visokolegovanogo bilogo chavunu. Naukovi visti Nacional'nogo tehnichnogo universitetu «KPI», 1 .

[24] Jamshinskij, M. M., Radchenko, K. S., Fedorov, G. E., Platonov, E. A. (2014). Povyshenie sluzhebnyh svojstv $\mathrm{Cr}-\mathrm{Mn}$-chuguna kompleksnym modificirovaniem. Metallurgija. Mashinostorenie, $2,22-26$.

[25] Jamshinskij, M. M., Radchenko, K. S., Fedorov, G. E., Platonov, E. A. (2013). Sluzhebnye harakteristiki mikrolegirovannyh i modificirovannyh belyh chugunov. Lit'e i metallurgija, 4, 29-35.

[26] Radchenko, K. S., Jamshins'kij, M. M., Fedorov, G. E., Platonov, E. A. (2014). Izotermichnij stupinchastij vidpal hromomargancevih chavuniv. Visnik DDMA, 1, 218-223. 